Vol. 2, No. 1, June 2021

DOI: https://doi.org/10.18196/ijiep.v1i2.11759

\title{
Mitigation-Based Enlightenment Da'wah (Social Movement of MDMC Sulawesi-Southeast in Psychological Assistance to COVID-19 Survivors)
}

\author{
${ }^{1}$ Muhammad Alifuddin, ${ }^{2}$ Moh. Toriqul Chaer*, ${ }^{3 S}$ ukatin Sukatin \\ ${ }^{1}$ Institut Agama Islam Negeri Kendari, Indonesia \\ 2Sekolah Tinggi Agama Islam Masjid Syuhada Yogyakarta, Indonesia \\ ${ }^{3}$ Institut Agama Islam Nusantara Batang Hari Jambi, Indonesia \\ *Corresponding email: m.thoriq@staimsyk.ac.id
}

ARTICLE INFO

Article history

Received, 15/05/2021

Revised, 26/05/2021

Accepted, 27/05/2021

Keywords

Da'wah

Mitigation

Social Movement

COVID-19

Pandemic

\section{ABSTRACT}

This study aims to describe the mitigation-based MDMC enlightenment da'wah in handling the impact of the pandemic, especially providing psychological assistance to the COVID-19 survivors' community. Research data were obtained through in-depth interviews, observation, and document review. All data obtained were analyzed using the Miles and Huberman paradigm. The results showed that Muhammadiyah first carried out mitigation-based enlightenment da'wah through various social activities by providing public awareness in dealing with the COVID-19 pandemic. Second, da'wah based on a mitigation approach was carried out by the Southeast Sulawesi MDMC, with three approaches, an oral approach, brochures, and social media. The bil hal or bi al-amal approach was carried out through measured and planned actions, such as spraying disinfectants, distributing masks, sharing food, and providing scholarships to survivors. Third, the enlightenment da'wah based on the mitigation movement conducted by MDMC was inclusive and universally humanitarian oriented. This activity has proven to improve the psychological condition of the COVID-19 survivors. The pandemic period requires physical distancing, but social attachment must be solid because caring for each other can reduce stress levels and make the body's immune stronger.

This is an open access article under the CC-BY-SA license.

\section{Citation:}

Alifuddin, M., Chaer, M.T., \& Sukatin, S. (2021). Mitigation-based enlightenment da'wah (social movement of MDMC Sulawesi-Southeast in psychological assistance to Covid-19 survivors). International Journal of Islamic Educational Psychology, 2(1), 84-103. DOI: https://doi.org/10.18196/ijiep.v1i2.11759 
Alifuddin, Chaer \& Sukatin | Mitigation-Based Enlightenment Da'wah (Social Movement of MDMC Sulawesi-Southeast in Psychological Assistance to COVID-19 Survivors)

\section{INTRODUCTION}

At the end of 2019, the world was shocked by the COVID-19 outbreak that hit Wuhan, China. Tens of thousands of Chinese people, especially Wuhan residents, were infected with coronavirus (Media, 2020; Supriatna, 2020; Misno et al., 2020). Coronavirus infected 200 countries quickly and caused 3.3 million deaths as of May 2021 (Media, 2021). Based on Worldometers data, the total cases of coronavirus infection worldwide have reached 163,694,333 cases. Of that number, 3,392,634 people died, and 142,144,554 people were declared recovered (Media, 2021; Fuadi \& Irdalisa, 2020). Society felt the impacts, the upper, middle, and lower classes. Various fields such as economic, educational, social, and tourism also suffer from this outbreak (Kane et al., 2020; Sohrabi et al., 2020).

In Indonesia, COVID-19 began in early March. The government then issued Presidential Decree (Kepres) Number 12 of 2020 regarding Non-Natural Disasters of Coronavirus Disease 2019 (COVID-19) as a National Disaster (KEPPRES No. 12 Tahun 2020 Tentang Penetapan Bencana Nonalam Penyebaran Coronavirus Disease 2019 (COVID-19) Sebagai Bencana Nasional [JDIH BPK RI], 2020). The COVID-19 outbreak as a national disaster was responded to by the Muhammadiyah Disaster Management Center (MDMC) by establishing the Muhammadiyah COVID-19 Command Center (MCCC) from the center to the regions (Subiyanto, 2020).

Responses to a disaster for Muhammadiyah are nothing new as a social organization. Muhammadiyah, through the Muhammadiyah Disaster Management Center (MDMC), is always present and actively involved in every disaster at local, national, and global levels. Quantitatively, every year Muhammadiyah responds to 50 to 70 disasters (Republika Online, 2019). Therefore, MDMC recognition as one of the disaster management institutions has a concern for every disaster.

In a press release, Lembaga Kajian Strategis dan Pembangunan (LKSP) stated that Muhammadiyah is a social organization or institution that cares the most in dealing with COVID-19 in Indonesia (Republika Online, 2020). The LKSP's acknowledgment, as quoted above, sparks the need for an in-depth study of the patterns, motives, and how MDMC carries out the mitigation-based da'wah of enlightenment activities in Southeast Sulawesi. Besides an effort to examine the form or pattern of mitigation, this study also questions whether mitigation-based da'wah is based on universal humanitarian principles and can be free from the network of sectarianism and religion or vice versa (Baidhawy, 2015).

The question above becomes essential, considering that the fundamental idea of Muhammadiyah, as stated in its articles of association, is as a da'wah movement. In contrast, the word "da'wah" itself attaches an element of mission to "influence". In the context of Islam, da'wah is a process to influence a person and or group of people to become closer to "Islam" (Islamization) (Nurhayati et al., 2018). 
Alifuddin, Chaer \& Sukatin | Mitigation-Based Enlightenment Da'wah (Social Movement of MDMC Sulawesi-Southeast in Psychological Assistance to COVID-19 Survivors)

Based on the observations, until the end of November, Muhammadiyah continued to educate the public to use masks and provide scholarships to several students (Faktual.Net, 2020). Thus, Muhammadiyah continues to move, educate, help, and lighten the burden of some survivors, which is this organization's honest, solid, and philanthropic character. Hafidz Arfandi said that Muhammadiyah community philanthropy is not too interested in religious polemics. Muhammadiyah is more inclined to humanitarian work, generosity, love, and care for others. Thus, efforts to prove the truth of social and humanitarian movements by Muhammadiyah are not urgent because of this common-sense (Arfandi, 2020).

This study investigates disasters in perspective and how Muhammadiyah mobilizes its social activities within the framework of da'wah. Disasters in Muhammadiyah's perspective, including the COVID-19 pandemic, are not seen as unfavorable. However, the logical consequence of this view requires Muhammadiyah; (1) promoting awareness about the importance of environmental protection and risk management of vulnerability, and (2) focusing on implementing disaster relief and recovery initiatives which include disaster mitigation and anticipation (Baidhawy, 2015).

The first closely related aspect to the community's mindset is the impact of disasters and their understanding of reality in all dimensions. During the COVID-19 pandemic, based on the findings of several studies, some areas intersected with religious values and experiences. For example, Hanan, Syattar, and Sabara's results mentioned that the acceleration of the COVID-19 response in many countries, including Indonesia, was conservatism and rigidity in understanding religion during the pandemic. In this context, religious moderation during the COVID-19 pandemic is a necessity.

Moderate chooses a rational response to COVID-19. It separates religion from science and places both in a dialogical and integrative way. Meanwhile, the inclusiveness dimension in moderatism requires willingness and self-awareness. All COVID-19 mitigations have been mutually agreed upon based on consensus government policies. Moderation in a contextual sense means that understanding COVID-19 requires comprehensive observations and attitudes. Considering sociological aspects such as cultural dimensions, social systems, and patterns of community interaction (Hannan, 2020; Sabara, 2020; Syattar et al., 2019). Up to this point, it is appropriate to question "mitigation-based da'wah" promoted by Muhammadiyah, whether in that sentence the movement to build Islamic reasoning that integrates religion, science, and government policy, is accommodated in the mitigation-based enlightenment propaganda movement. If yes, then what are the forms, methods, and approaches?

Another critical aspect of mitigation-based da'wah activities is the sentence: "COVID-19 Impact Management, Open Donations for Da'wah and Humanity," which seems "paradoxical". Da'wah is essentially an active "negotiating value" of religion that is not so "sterile" because da'wah sometimes, not to mention always, 
Alifuddin, Chaer \& Sukatin | Mitigation-Based Enlightenment Da'wah (Social Movement of MDMC Sulawesi-Southeast in Psychological Assistance to COVID-19 Survivors)

becomes a bridge to internalize values based on strengthening group identity (culture and or religion). Meanwhile, the fundamental idea of "mitigation" activity is in the social space and is universal across regions, cultures, and beliefs. Even so, it is not impossible to cooperate with da'wah with active mitigation, which is carried out "purely" for universal humanity without having to be trapped in "missionary" activities.

Many researchers conducted studies on Muhammadiyah's role in disaster mitigation, like Zakiyuddin Baidhawy, entitled The Role of Faith-based Organization in Coping with Disaster Management and Mitigation Muhammadiyah's Experience. Baidhawy's study explored Muhammadiyah's theological stance on disasters; its roles and strategies in disaster management and mitigation. This study shows several things: First, Muhammadiyah views disaster positively. Second, as a consequence, Muhammadiyah promotes awareness and importance of environmental protection and risk and vulnerability management.

Second, Muhammadiyah established the Muhammadiyah Disaster Management Center (MDMC), which focuses on implementing disaster relief and recovery initiatives, including disaster mitigation and anticipation through Disaster Prepared Schools and Disaster Prepared Hospitals. Muhammadiyah (MDMC) is guided by al-Ma'un theology and the principle of universal humanism (al-nas), building a relationship of understanding (ta'aruf), cooperation (ta'awun), and fulfillment of the rights of survivors. Muhammadiyah, through MDMC, cooperates with various community parties at local, national, and international levels. Thus, Muhammadiyah can escape the da'wah trap (sectarian) and assist all victims and survivors in a non-discriminatory manner (Baidhawy, 2015).

Besides Baydhawy, Kiki Rasmala Sari conducted a study, entitled Peran Lembaga Muhammadiyah dalam Mitigasi Bencana di Kabupaten Sinjai. Sari's findings concluded that LPB Muhammadiyah, to mitigate disasters, still encountered many obstacles, so synergy with other institutions was needed (Sani \& Syamsuddin, 2020). Abdul Sakban had a research entitled Peran MDMC dalam Pelayanan Pendidikan dan Psikososial untuk Anak Terdampak Gempa Bumi di Kabupaten Lombok Utara. He found that MDMC's significant role in providing educational and psychosocial services could positively influence earthquake victims, especially children (Sakban et al., 2020).

Putra Agina Widyaswara Suwaryo wrote a study called Peran Muhammadiyah Disaster Management Center Dalam Mitigasi Bencana. He stated that MDMC took part in disaster mitigation in Kebumen Regency, such as active involvement in disaster socialization and facilitating a Disaster Resilient Village. Meanwhile, the difficulty faced was that the role of all MDMC members in contributing to disaster management was not yet optimal, starting from pre-, emergency response, and post-disaster (Suwaryo et al., 2020). Although some studies' focus regarding MDMC mitigation activities is similar, they have a different subject, locus, and focus. Therefore, this study seeks to explain the MDMC mitigation 
activities as an integral part of enlightenment da'wah activities in tackling the impact of the COVID-19 outbreak.

Meanwhile, Engkos Kosasih, et al studied Literasi Media Sosial dalam Pemasyarakatan Moderasi Beragama dalam Situasi Pandemi COVID-19 (2020). The results indicated that during the COVID-19 pandemic, modern humans as social media users must treat them with a modest or fair attitude when receiving the information. The community as social media users must classify and choose what is acceptable and what should be rejected, especially those related to religious issues, such as various hoaxes spread through social media (Kosasih et al., 2020).

\section{METHODOLOGY}

This study is expected to provide a detailed explanation of why and how Muhammadiyah combines da'wah activities with interest-free social services. In this context, the case study method was chosen to accurately describe the reality of the moderation movement carried out by Muhammadiyah in the pandemic through mitigation-based enlightenment da'wah.

The subject of this research was the Muhammadiyah Kendari community. Experiences and empirical facts as shown by the Muhammadiyah community in carrying out the mitigation movement, through this research tried to be described critically and analytically so that authors needed to conduct data mining through observation, reference studies, and in-depth interviews.

Based on the type of research approach used, local Muhammadiyah leaders, community leaders, traditional leaders, and religious leaders searched for information related to the focus of the research problem. First, the authors analyzed data using a hermeneutic phenomenological approach by Von Eckartsberg (see Madjid, 2014). Then, they were combined with the data analysis mechanism of Miles and Huberman (Moustakas, 1994; Miles \& Huberman, 1986).

\section{FINDINGS}

\section{1) Southeast Sulawesi MDMC Historical Sketch}

The basis of LPBM/MDMC is the Decree of the 46th Muhammadiyah Congress in 2010. As an integral part of organizational decisions, MDMC is spread to some regions. Although a managerial decision, the Southeast Sulawesi MDMC was only established on June 12, 2019. Muhammadiyah has already carried out new disaster management works before. As a social organization, the Southeast Sulawesi Muhammadiyah has never been absent in social movements and activities for the community, not only for Southeast Sulawesi but also across regions and provinces. Before MDMC, the social action of the Muhammadiyah community was facilitated by the Majelis Pembina Kesejahteraan Sosial (MPKS) (Interview Results with Al-Jufri, 2020). 
Various disaster events, especially those that occurred in Sulawesi-Southeast, are never deserted from the presence of Muhammadiyah. For example, the flash flood that hit Kendari in June 2015 was shocking. The overflowing water from the Wanggu river that divides Kendari City was declared the worst flood event in the last ten years. The overflow of water reached 1 to 1.5 meters, forcing several residents to be evacuated. The flood incident woke Muhammadiyah. Even LPB PP Muhammadiyah went to help directly and coordinated with the Southeast Sulawesi Muhammadiyah Regional Leadership to show empathy and ease the victims (Interview with Al-Jufri, 2020).

The North Konawe flood disaster in 2017 also received serious attention from Muhammadiyah residents, especially the Muhammadiyah Student Association or Ikatan Mahasiswa Muhammadiyah (IMM). Through charity activities for North Konawe, the younger generation of Muhammadiyah also helped. IMM involved some Muhammadiyah resources and infrastructure to assist. One year later, in 2018, the same flood happened again. Muhammadiyah family also contributed their resources to help the affected community, such as ambulance, members, and cadres of the Muhammadiyah Student Association or Ikatan Mahasiswa Muhammadiyah (IMM) (Interview Result with Syukur, 2020). Due to the prone to floods geographical conditions of Southeast Sulawesi, on June 12, 2019, the Muhammadiyah Disaster Management Agency (LPB) officially established Muhammadiyah Disaster Management Center (MDMC). This organization aims to organize and coordinate all organizational activities in disaster management (Sani \& Syamsuddin, 2020).

\section{2) MDMC Roles and Functions}

Muhammadiyah Disaster Management Center (MDMC)/LPBM coordinates resource mobilization in Disaster Emergency Response, Disaster Mitigation and Preparedness, and Post-Disaster Rehabilitation. Muhammadiyah is interested in having its perspective on disasters, especially the second point of Muhammadiyah's Articles of Association: Social life is the sunnah (qudrat iradat law) of Allah for human life. Meanwhile, Muhammadiyah also believes that social life will achieve its goals by organizing according to QS. Ali Imran (3): 104. Therefore, a framework of reference in dealing with disasters is drawn up.

In contrast, for Muhammadiyah, a disaster is "a serious inconvenience caused by natural and human factors, which usually paralyzes the functions of a society built to sustain life, protect environmental sustainability assets and ensure their dignity as human beings and as part of religious orders. The paralysis of these functions is due to the occurrence of human, material, economic or environmental losses that extend and exceed the ability of the affected community or community to cope using their resources." (PP. Muhammadiyah, 2015). 
Efforts to overcome disasters become necessary for Muhammadiyah, considering that the basis of this organization is as a social movement to provide social services to the people. MDMC was established with the vision: "Developing superior disaster management functions and systems based on Penolong Kesengsaraan Oemoem (PKO) to improve the quality and progress of people's lives who are aware and resilient to disasters and can recover disaster victims quickly and with dignity". The vision above is translated into the following missions: (1) improving and optimizing disaster management systems in Muhammadiyah, (2) developing disaster awareness in the Muhammadiyah environment, (3) strengthening community networks and participation in disaster management (Quoted from the official website (MDMC, 2019).

\section{3) MDMC's Movement and Activity Patterns in Handling COVID-19}

MDMC/LPB Muhammadiyah Southeast Sulawesi was only established in 2020, but its work appears increasingly accurate in the community. MDMC activists show their concern for every disaster that happens to the community. Humanitarian officers of Muhammadiyah, Southeast Sulawesi, continue to encourage social activities to help the community overcome the disasters. One of the disaster events that Muhammadiyah responded quickly, in this case, was COVID-19 (Interview Results with Al-Jufri, 2020).

MDMC/LPB Muhammadiyah Southeast Sulawesi was only established in 2020, but its work appears increasingly accurate in the community. MDMC activists show their concern for every disaster that happens to the community. Humanitarian officers of Muhammadiyah Southeast Sulawesi continue to encourage social activities to help the community. One of the disaster events that Muhammadiyah responded quickly, in this case, was COVID-19 (Interview Results with Al-Jufri, 2020).

\section{a) Sterilization of public facilities}

According to experts, COVID-19 can spread through particles from a patient's sneeze or a cough that sticks to other objects such as clothes or other entities. Therefore, one approach to prevent transmission of this virus is to use antiseptics and disinfectants. In that context, several institutions have taken creative initiatives to spray disinfectants, especially in potential places and public facilities for COVID-19 transmission. The Sulawesi-Southeast MDMC also took this step, even to help the wider community and massively the Sulawesi-Southeast MDMC, in collaboration with the University of Muhammadiyah Kendari (UMK), produces disinfectants from plant materials. Efforts to make disinfectants are carried out as one of the efforts of Muhammadiyah elements in helping the community. Disinfectants made by MCCC/MDMC and UMK, as mentioned, are used for some houses of worship and educational institution buildings and distributed free to the public (factual.net, 2020). 
In addition, MDMC sterilizes hundreds of places of worship (mosques, churches, and temples), schools, and facilities such as ports by spraying disinfectant (https://bumisultra.com/news, 2020). Anticipatory steps in spraying disinfectants to sterilize public places or facilities by MDMC mobilize Muhammadiyah volunteers from the Muhammadiyah Youth Force (AMM). MDMC conducted this activity in March and April 2020.

\section{b) MDMC Food Sharing Program}

The COVID-19 pandemic in Indonesia has a multi-dimensional impact from a social, cultural, and economic perspective. From an economic perspective, the pandemic has caused some people to lose their livelihoods due to the closure of some industries and public shopping facilities that previously accommodated many workers. This reality creates a multi-effect player with a significant impact on the socioeconomic life of the community. Under these conditions, these people who previously relied on the income to make ends meet were forced to lose the job.

Responding to this reality, MDMC nationally issued a notice to Muhammadiyah followers to take an active role in overcoming the impact of food shortages due to COVID-19 through the Family Food Security Movement or Gerakan Ketahanan Pangan Keluarga (Getapak) (Muhammadiyah Inisiasi Gerakan Ketahanan Pangan Keluarga, 2020). As a follow-up of the "Getapak", the Regional Leadership of Muhammadiyah Sulawesi-Southeast through LAZISMU issued a notice. It appealed to the organization members to participate actively according to their respective abilities to help fellow Muslims. In that context, Muhammadiyah Southeast Sulawesi launched the "Muhammadiyah Sharing" program.

The "Muhammadiyah Sharing" program started from March to August 2020 to show empathy from Muhammadiyah to the community. At the beginning of the outbreak, in March, MDMC/MCCC went directly to share food with the poor community groups in Kendari and several villages in South Konawe.

Before Ramadan 2020, the "Muhammadiyah Sharing" program targeted poor community groups. This activity aimed to help the affected community groups to enjoy Ramadan like others at least. MDMC food sharing program had a tagline "Happy before Ramadan" (Interview Result with Syukur, 2020). Muhammadiyah food sharing program was revived during Ramadan and then continued to the end of Ramadan by distributing the zakat fitrah to the community by the COVID-19 pandemic (Telisik.Id, 2020).

The food sharing movement was not MDCM's primary responsibility. Several amil zakat institutions and government institutions were also doing the same program. Therefore, to avoid overlapping food aid 
allocations and the possibility of repeated distribution to the same subject, the sharing movement initiated by MDMC referred to the mustahik mapping data by LAZISMU (Amil Zakat Infak and Sadakah Muhammadiyah) (Interview with Syukur, 2020). The Muhammadiyah movement to share food also distributed qurban meat to several communities in Kendari, Konawe, and South Konawe. In addition, the campaign to share qurban meat in a pandemic situation was organized by MDMC and some amil zakat institutions under BASNAS of Southeast Sulawesi (Interview with Arsam, 2020).

\section{c) Masks Sharing and Socialization}

The COVID-19 pandemic is the outbreak of the SARS-CoV-2 viruses that attack people and occurs massively and simultaneously in several countries, causing many victims. Some experts see the COVID-19 outbreak as a severe disease due to much damage to the body caused by microscopic organisms (Emmeluth, 2010). The COVID-19 pandemic is a massive spread of disease outbreaks by the coronavirus simultaneously in some countries globally, so the WHO declared it a pandemic (Valerisha \& Putra, 2020).

Epidemiologically, COVID-19 can spread quickly because the SARS-Cov2 is an entirely new virus. No one in this world has immunity to this virus. As a result, each COVID-19 case can cause 2-3 new issues. WHO (World Health Organization) officially declared the coronavirus disease (COVID19) as a pandemic on March 9, 2020, due to this rapid spread (COVID-19, 2020). Countries worldwide are trying their best to break the spread to finally make efforts (social and physical distancing) (Smith, \& Freedman, 2019). Another protocol implemented to avoid the spread of COVID-19 is the recommendation to wash hands and wear masks (Anggraini, 2020).

The recommendation to wear masks is related to two main indications to avoid transmitting the virus; through droplets from the respiratory tract and contact. Droplets or tiny droplets between 5 to 10 micrometers in diameter contain viral particles produced when a person coughs or sneezes. Therefore, every person who is in close contact (within $1 \mathrm{~m}$ ) with an indicated person to experience or show symptoms of respiratory distress (coughing, sneezing) has the potential to be exposed to droplets so that it is possible to cause infection.

Droplets are also likely to fall on surfaces where the virus can remain active. Hence, the closest area to the infected person can become a source of transmission (Water, sanitation hygiene, and waste management) (World Health International, 2020). Therefore, recommendations for wearing masks help protect healthy people (self-protection when interacting with infected people) or control sources (Ardiputra et al., 2020; Estri et al., 2019). 
Since the beginning of the pandemic, there has not been a single study that can firmly confirm when the pandemic will end, especially in the economic and educational fields. On this basis, since May 29, 2020, the government has issued a New Normal policy.

According to Ahmad Yurianto, the new normal is a new order, habit, and behavior based on adaptation to cultivate clean and healthy living behavior. This approach includes regularly washing hands with soap, wearing masks, maintaining a safe distance, and avoiding crowds. The government hopes that the new habit can soon become a collective consciousness to run well. This policy is expected to be implemented immediately by managers of public facilities, workplaces, schools, and places of worship (Tirto.id, 2020).

Responding to government policies regarding the recommendation to wear masks to the public as a preventive measure in preventing the transmission of the SARS-Cov-2 virus, Muhammadiyah, as an integral part of Indonesia, is committed to assisting the community and government in realizing a healthy system and environment. Therefore, Muhammadiyah also went directly to help and distribute masks to the public, such as in markets, streets, and other crowded places. Muhammadiyah Youth Force and Aisyiyah distributed the masks in March and April 2020 in the Konawe Regency (Kampung, 2020).

Socialization to educate the public to wear masks consistently continues. For example, at the end of October and early November, MDMC again distributed 9,000 masks to the public. The movement for sharing and socializing masks belongs to Muhammadiyah's commitment to tackling and preventing the transmission of COVID-19 (Factual.net, 2021).

\section{d) Scholarships}

As previously mentioned, the COVID-19 pandemic has had a broad impact or touched almost all dimensions of human life, including education. The government has decided to close educational institutions to contain the spread of coronavirus temporarily. This condition is factually "disturbing" the continuity of the learning process between students and teachers. In this context, all elements of education, especially the state, are undoubtedly responsible for facilitating the schools for all educational stakeholders to carry out safe learning and can protect students from potential virus exposure (Siahaan, 2020; Martoredjo, 2020)

As the responsibility for the government and other social elements to continue the transfer of knowledge process for students, learning from home or online learning was adopted. The policy can protect the teaching participants and provide a sense of security. Changes in teaching models and patterns from previously conducted face-to-face to online learning, of course, have a significant influence, including in financing. 
Online learning requires internet data. This reality is, of course, an additional economic burden for the family from a lower financial group. In that context, Muhammadiyah, as part of the social element of Indonesian society, feels the responsibility. Hence, Muhammadiyah must make creative efforts in providing solutions.

Muhammadiyah's concern through MDMC is by providing pandemic scholarships to some educational subjects. Donations and scholarships from Muhammadiyah are this organization's concern to continue the educational process during the pandemic. Scholarships were given to 40 students, especially those students with high achievement. According to Muhammad Syukur, the scholarship compensation funds came from the infaq and sadaqah from Muhammadiyah members (Interview with Syukur, 2020).

\section{e) Worship Guidance during the Pandemic}

The COVID-19 pandemic has empirically had a significant influence on almost all aspects of human life, including religious rituals. There are recommendations to comply with health protocols to prevent the spread of the SARS-Cov-2, such as maintaining distance, wearing masks, maintaining cleanliness, and changing worship patterns. Muhammadiyah, as a religious organization with relatively large members, considers it essential to conduct an in-depth study of worship patterns involving many people. As a follow-up to in-depth research implementing certain worship services, Muhammadiyah issued several edicts containing guidelines for worship during the early outbreak and the new normal era. The PP Tarjih Council issued guidance for worshipping during the pandemic. Muhammadiyah members gradually socialize the community to understand the pandemic without feeling constrained in carrying out certain rituals. The demand for worship is stated in the Muhammadiyah Central Executive Number 06/EDR/I.0/E/2020 concerning Guidance for Fasting, Arafah Fasting, Eid al-Adha, Qurban(sacrifice of a livestock animal during Eid al-Adha), and the Protocol for Eid al-Adha Celebration during the COVID-19 Pandemic (covid19.muhammadiyah.id, 2020).

\section{DISCUSSION}

1) Dimensions of Da'wah in the COVID-19 Mitigation Activities by MDMC The Southeast Sulawesi MDMC conducted at least eleven activities to mitigate non-natural disasters caused by the coronavirus. MDMC as Muhammadiyah's representative, did the eleven series of activities to show deep concern for the community affected by COVID-19, dedication, and sincerity to help ease the burden. The eleven MDMC mitigation activities are as follows. 
Alifuddin, Chaer \& Sukatin | Mitigation-Based Enlightenment Da'wah (Social Movement of MDMC Sulawesi-Southeast in Psychological Assistance to COVID-19 Survivors)

Table 1. Southeast Sulawesi Muhammadiyah Disaster Management Center Mitigation Activities

\begin{tabular}{|c|c|c|c|c|}
\hline No. & Time & Time and Activities & Targets & $\begin{array}{l}\text { Mitigation } \\
\text { Type }\end{array}$ \\
\hline 01 & March 2020 & Spraying Disinfectant & $\begin{array}{l}\text { Schools, houses } \\
\text { of worship, other } \\
\text { public facilities }\end{array}$ & $\begin{array}{l}\text { Structural } \\
\text { Mitigation }\end{array}$ \\
\hline 02 & March 2020 & Disinfectant Distribution & Public & $\begin{array}{l}\text { Structural } \\
\text { Mitigation }\end{array}$ \\
\hline 03 & March 2020 & $\begin{array}{l}\text { Distribution of Food } \\
\text { Packages }\end{array}$ & $\begin{array}{l}\text { Poor } \\
\text { neighborhoods }\end{array}$ & $\begin{array}{l}\text { Structural } \\
\text { Mitigation }\end{array}$ \\
\hline 04 & March 2020 & $\begin{array}{l}\text { Socialization and mask } \\
\text { distribution }\end{array}$ & Public & $\begin{array}{l}\text { Structural } \\
\text { Mitigation }\end{array}$ \\
\hline 05 & April 2020 & $\begin{array}{l}\text { Distribution of Food } \\
\text { Packages }\end{array}$ & $\begin{array}{l}\text { Poor } \\
\text { neighborhoods }\end{array}$ & $\begin{array}{l}\text { Structural } \\
\text { Mitigation }\end{array}$ \\
\hline 06 & $\begin{array}{l}\text { April-June } \\
2020\end{array}$ & $\begin{array}{l}\text { Socialization of worship } \\
\text { during the pandemic }\end{array}$ & $\begin{array}{l}\text { Poor } \\
\text { neighborhoods }\end{array}$ & $\begin{array}{l}\text { Structural } \\
\text { Mitigation }\end{array}$ \\
\hline 07 & May 2020 & $\begin{array}{l}\text { Distribution of Food } \\
\text { Packages }\end{array}$ & $\begin{array}{l}\text { Poor } \\
\text { neighborhoods }\end{array}$ & $\begin{array}{l}\text { Structural } \\
\text { Mitigation }\end{array}$ \\
\hline 08 & June 2020 & $\begin{array}{l}\text { Distribution of Qurban } \\
\text { meat }\end{array}$ & $\begin{array}{l}\text { Poor } \\
\text { neighborhoods }\end{array}$ & $\begin{array}{l}\text { Structural } \\
\text { Mitigation }\end{array}$ \\
\hline 09 & October 2020 & $\begin{array}{l}\text { Socialization and } \\
\text { distribution of } 9000 \\
\text { masks }\end{array}$ & Public & $\begin{array}{l}\text { Structural } \\
\text { Mitigation }\end{array}$ \\
\hline 10 & $\begin{array}{l}\text { October- } \\
\text { November } \\
2020\end{array}$ & $\begin{array}{l}\text { Continued socialization } \\
\text { and distribution of } \\
\text { masks }\end{array}$ & Public & $\begin{array}{l}\text { Structural } \\
\text { Mitigation }\end{array}$ \\
\hline 11 & $\begin{array}{l}\text { November } \\
2020\end{array}$ & $\begin{array}{l}\text { Scholarships for students } \\
\text { affected by COVID-19 }\end{array}$ & College students & $\begin{array}{l}\text { Structural } \\
\text { Mitigation }\end{array}$ \\
\hline
\end{tabular}

Source: (Muhammadiyah Disaster Management Center (MDMC) Sulawesi Tenggara)

The eleven activities or mitigation activities by MDMC are categorized as sterilization, social assistance, and socialization. These activities are in an integrated manner or connected and contain an element of socialization.

Sterilization protects public facilities from virus transmission. Spraying disinfectants is a genuine concern and socialization to maintain personal and environmental hygiene as recommended by the government to reduce the virus. Likewise, the mask distribution also contains socialization to protect oneself and others from virus exposure. MDMC's food sharing activities reminded others to take care of themselves and the people around them (Interview with Arsam, 2020).

Mitigation activities by MDMC show the explicit efforts of Muhammadiyah to mobilize and or build public awareness to take preventive steps and actions to maintain health through oral, written, and action messages. The action 
sequence is the implementation or actualization of the command yad' una ila alKhair (calling on goodness).

Positive actions (al-Khair) seem explicit to maintain personal hygiene and public facilities through spraying disinfectants, protecting themselves by practicing new traditions, such as wearing a mask (amru bi al-makruf), from dangerous virus transmission (nahyu 'an al-Munkar). Furthermore, in Islamic teachings, maintaining human survival (hifz al-nafs) is the foundation in religious orders, so that calls and invitations (socialization) to heed health protocols as an integral part of survival.

Based on the indications mentioned, MDMC mitigation actions are an inseparable part of the da'wah and parts of the da'wah movement.MDMC's disaster mitigation activities also have conceptual historical reasons related to Muhammadiyah's initial inspiration based on Al-Imran: 104, which substantially commands to make changes through the da'wah movement. Article 4 Paragraph 1 of the Articles of Association of Muhammadiyah states that Muhammadiyah is an Islamic Movement, Da'wah Amar Ma'ruf Nahi Munkar, and Tajdid, based on the Qur'an and As-Sunnah. Furthermore, article 7, Paragraph 1 states that to achieve its aims and objectives, Muhammadiyah carries out Da'wah Amar Ma'ruf Nahi Munkar, and Tajdid manifested in efforts in all areas of life. Therefore, by relying on these arguments, all Muhammadiyah's activities equal da'wah.

Referring to the activities within Muhammadiyah in the Articles of Association, the entire series of MDMC's mitigation activities from March to November 2020 are da'wah oriented as the message conveying Islam to all humankind (QS Al-Imran: 104, 110, 114) and mercy, creating, actualizing, and operationalizing Islam as a religion of grace (capable of prospering, being happy, and becoming a solution) (Surah al-Anbiya': 107). Thus, the nonnatural disaster mitigation of COVID-19 by MDMC, in addition to Islamic normative values, builds and changes human character towards a better direction (Khaidir, E., \& Suud, FM 2020). Furthermore, the da'wah movement also has the dimension of developing the socio-cultural life of humanity towards continuous change for the better (Tampubolon, 2016).

\section{2) Mitigation-Based Da'wah: MDMC Strategies, Approaches and Methods}

MDMC's activities during the pandemic clearly show that Muhammadiyah actively plays a role and helps the government overcome the impact of nonnatural disasters. Muhammadiyah supports the government. MDMC document analysis related to COVID-19 mitigation shows that MDMC fieldwork is not sporadic but planned. It is based on the da'wah governance system through the stages of structuring strategy, selecting an integrative da'wah approach and method.

MDMC activists' several stages before mitigation: (1) the planning stage includes the activity's objectives, a pattern of communication, the target 
audience, and designing the message material. The message material compiled is about COVID-19 and all issues related, (2) the second stage is selecting the activity, testing the design of the mitigation strategy model. In conducting the trial, if there are still shortcomings, the activists will make various improvements. In contrast, if suitable, the model can be applied with several enhancements. Therefore, this model of risk communication strategy for disaster preparedness can be involved in risk communication activities to the community.

Based on the strategic design mentioned above, MDMC moves by mobilizing volunteers to work simultaneously and in an integrated manner to mitigate. MDMC carries out efforts to actualize the strategic plan as mentioned through a specific approach to run effectively. In implementing mitigation-based da'wah, according to the authors' observations, the MDMC community is more dominant in taking a social approach, based on the recipient/ partner of da'wah related and dependent on other people.

This approach is carried out through education, cultural and socio-economic interactions. The disinfectants and the mask distribution aim to educate the public to apply and create a protected situation from possible virus transmission through objects. Likewise, the mask distribution encourages the value of education to create public awareness to wear masks. On the other hand, the MDMC mitigation program also uses a socio-economic approach to build food security, especially for the poor and workers who have lost their income due to COVID-19. MDMC's social approach strengthens food security and providing scholarships to several students.

Mitigation activities by MDMC, if examined from the da'wah method perspective, have at least three methods.

a) MDMC adopts the $d a^{\prime}$ wah bi al-lisan method by equipping volunteers with COVID-19 knowledge so that all volunteers can explain to the public the importance of protecting themselves, their families, and the environment from potential exposure to the SARS Cov2 virus. Muhammadiyah preachers also carry out this bi al-lisan method regarding the guidance of worship in the pandemic era, related to congregational prayers, Friday prayers, Eid prayers, and the slaughter of sacrificial animals. Based on the authors' observations, the socialization based on PP Tarjih Council's decision is online.

b) The da'wah bi al-kitabah method is a call to prevent and protect oneself from the dangers and threats of exposure to Covid-19 by distributing reminders. However, in this context, the MDMC Sulawesi-Southeast is generally only forward from the Central MCCC. Therefore, implementation of mitigationbased da'wah through oral and written by MDMC is adopted by Muhammadiyah following the strategy of preaching enlightenment (tanwir), according to the current context. This method is expected to answer these latest problems, which is believed by Muhammadiyah at this 
time, as a da'wah movement, bringing people from ignorance, misery, and poverty to empowerment, welfare, health, and intelligence (Amirrahman et al., 2015).

c) The da' wah bi al-hal method is the most dominant. Fieldwork on sterilization through spraying disinfectants, mask distribution, food security compensation, and scholarships is in the ideas and strategic plans. It touches the community directly, especially the low economic class. $D a^{\prime}$ wah bi al-'amal, as during the pandemic, is not new for Muhammadiyah circles. The founder of Muhammadiyah, KH Ahmad Dahlan, had started this model and strategy and continuously encouraged attention to the poor, neglected children, built orphanages, and built medical centers, clinics, and maternity homes for the marginalized (mustadafin). This da'wah bil amal is a progressive and transformative interpretation of the Qur'an Surah alMa'un and the Qur'an Surah Al-Imran 104 and 110 by KH Ahmad Dahlan in 1912 (Qodir, 2019).

\section{3) Muhammadiyah Mitigation Da'wah in Southeast Sulawesi}

The commitment of Muhammadiyah da'wah as a humanitarian movement oriented towards efforts to empower mustadifin for society and national welfare is explicitly stated by Muhammadiyah entering the 21st century. The enlightenment da'wah movement develops strategies from revitalization (reinforcement) to transformation (dynamic change) to give birth to business charities and social actions that favor the mustad'afin and strengthen civil society (civil society) for the progress and welfare of the nation (Berita Resmi Muhammadiyah, PPM 2015: 79).

The da'wah movement for enlightenment is encouraged by Muhammadiyah, not to attract da'wah subjects into certain ideologies but to strengthen civil society for welfare. With this orientation, enlightenment da'wah in the social and humanitarian realm is truly socially oriented and universally humanitarian. If examined, the various enlightenment da'wah activities by MDMC activists in Southeast Sulawesi in the pandemic space for approximately 9 (nine) months are overall oriented towards strengthening civil society to understand the importance of protecting themselves and others. In addition, the strengthening targets the public regardless of religion, ethnicity, and organization to sterilize social facilities by spraying disinfectants in public facilities at schools, universities, mosques, churches, and monasteries.

Based on the authors' observations, the socialization of masks for the community by MDMC included public places such as markets, crossroads, public transport passengers, ship passengers (inter-island mass transit), street hawkers, and others who accessible to MDMC activists. The food sharing movement was based on the pattern found from the mapping results based on the target's need and urgency. The mapping aimed at the entire groups, considering that at the same time, the city and provincial 
governments, as well as BAZNAS, were doing activities to care for the COVID-19 humanity by MDMC (Interview with Gratitude, 2020).

Based on this reality, MDMC's activity in strengthening programs affected by COVID-19 is not based on certain religious, ethnic, and cultural groups. Still, it targets all elements of society based on their level of urgency. Thus, the mitigation-based da'wah of enlightenment does not depart from the basic ideas of Muhammadiyah about da'wah in entering the 21st century. Instead, da'wah develops strategies to strengthen and dynamic social change to business charities and social actions that favor vulnerable and marginal groups and support civil society (civil society) for the progress and welfare of the nation (Muhammadiyah Official News, PPM 2015: 79). In this context, the mitigation-based da'wah movement is inclusive, da'wah to empower and strengthen all by prioritizing universal human values.

The above reality is in line with Baidhawy's findings stating that the social movements by MDMC are based on the theological principles of al-Ma'un and universal humanism (al-nas), building social relations and mutual understanding between groups ( $\left.t a^{\prime} a r u f\right)$, ta'awun, and serious efforts to fulfill the rights of survivors. MDMC's social action in dealing with disasters cooperates with various groups at the local, national and international levels. Muhammadiyah's social movements and activities in coping with disasters carried out by MDMC managed to get out and distance themselves from sectarian da'wah's trap to touch all victims and survivors without any discriminatory space (Baidhawy, 2015).

\section{4) Limitations of Mitigation-Based Enlightenment Da'wah}

The various mitigation activities by the Sulawesi-Southeast MDMC over nine months are not easy for a new social institution. Therefore, it is customary to give appreciation for all activities and actions done. However, the Southeast Sulawesi MDMC needs to think about human resources with counseling skills.

MDMC can collaborate with various campuses with psychology majors or study programs or counseling guidance (Suud, F. M., et al., 2020) to psychologically assist the community or disaster survivors. This reality is important because, based on observations throughout the 9 (nine) months of the mitigation-based enlightenment program by MDMC SulawesiSoutheast, the aspect of psychological assistance is something untouched by MDMC. This online counseling service (e-counseling) can be pursued and developed on comorbid mood and anxiety disorders interventions, including transdiagnostic care and special psychological care. Beatty and Lambert stated that counseling services through the internet produced encouraging results. However, these interventions should be developed and targeted at treating comorbidities between various mental disorders and somatic disorders (Beatty \& Lambert, 2013; (Effendi et al., 2019). 
Alifuddin, Chaer \& Sukatin | Mitigation-Based Enlightenment Da'wah (Social Movement of MDMC Sulawesi-Southeast in Psychological Assistance to COVID-19 Survivors)

\section{CONCLUSION}

Referring to the findings and discussion of the mitigation-based enlightenment da'wah movement carried out by the Sulawesi-Southeast Sulawesi MDMC. First, the mitigation-based enlightenment da'wah by Muhammadiyah through various social activities aims to support the community in dealing with the COVID-19 pandemic. Second, the mitigation-based da'wah approach to enlightenment by MDMC Southeast Sulawesi has three approaches: (1) bil oral approach (socialization utilizing delivery through oral communication both in public places and in houses of worship); (2) the bil kitabah approach (through writing in the form of brochures and through social media messages), and (3) bil hal method, or measurable actions such as spraying disinfectants, distributing masks, sharing food, and providing scholarships to survivors. Third, the mitigation-based da'wah movement with a program to strengthen communities affected by COVID-19 is not based on certain religious, ethnic, and cultural groups but targets all elements of society based on their level of urgency.

In the future, it is crucial for the ranks of the Southeast Sulawesi-Sulawesi MDMC to think about the availability of human resources who have the skills to conduct counseling. Psychological assistance for residents affected by the COVID-19 pandemic with a trauma healing approach for residents, especially children and adolescents. Efforts to strengthen awareness needed by the victims are also provided as a complement to medical and physical assistance. Hopefully, the victims can resume their lives, return to their activities, and remain productive after the disaster. Other assistances include trauma healing with support therapy, mental health psychoeducation. Training local volunteers will help communities affected by disasters and distribute supplies. Psychoeducation or mentoring training for local volunteers is provided for those who help accompany disaster victims after the volunteers leave the location.

\section{REFERENCES}

Anggraeni, N. W. (2020). Pergulatan kebijakan dalam ko-evolusi pandemi global Covid 19. In Prosiding Seminar Nasional Problematika Sosial Pandemi Covid-19: Membangun Optimisme di Tengah Pandemi Covid-19. www.ojs.literacyinstitute.org/index.php/prosiding-covid19/index

Ardiputra, S., Prawira, M. R., Tasbir, M., Permata, S. U., Listiawati, N., \& Qadrini, L. (2020). Pembagian masker dan sosialisasi kebijakan pemerintah dalam rangka mendukung pencegahan penyebaran Covid-19 pada masyarakat Desa Pallis Kecamatan Balanip. Communnity Development Journal, 1(3), 395400. https://doi.org/10.31004/cdj.v1i3.1095

Arfandi, H. (2020). Motif dan strategi gerakan filantropi muhammadiyah. Jurnal Muhammadiyah

Studies,

1(1),

127-155.

https://doi.org/10.22219/jms.v1i1.11413 
Baidhawy, Z. (2015). The role of faith-based organization in coping with disaster management and mitigation: Muhammadiyah's Experience. Journal of Indonesian Islam, 9(2), 167-194. https:// doi.org/10.15642/JIIS.2015.9.2.167$\underline{194}$

Beatty, L., \& Lambert, S. (2013). A systematic review of internet-based self-help therapeutic interventions to improve distress and disease-control among adults with chronic health conditions. Clinical Psychology Review, 33(4), 609622. https://doi.org/10.1016/j.cpr.2013.03.004

COVID-19, W. R. P. (2020, July 2). Beranda. Covid19.go.id. https://covid19.go.id/

Effendi, D. I., Lukman, D., Eryanti, D., \& Muslimah, S. R. (2019). Advokasi Psikologis Bagi Masyarakat Terpapar Pandemi Covid-19 Berbasis Religious ECounseling. Digital Library UIN Sunan Gunung Djati Bandung

Estri, B. A., Putri, I. M., Rosida, L., \& Endriyani, A. (2019). Pengendalian dan Pencegahan Infeksi (PPI). Universitas 'Aisyiyah Yogyakarta.

Fuadi, T. M. \& Irdalisa. (2020). Covid 19: Antara Angka Kematian dan Angka Kelahiran. Jurnal Sosiologi Agama Indonesia (JSAI), 1(3), 199-211. https:// doi.org/10.22373/jsai.v1i3.767

MDMC Sultra Bagikan 9 Ribu Masker Secara Gratis Kepada Masyarakat. (2021, Mei). Faktual.Net. https://faktual.net/mdmc-sultra-bagikan-9-ribumasker-secara-gratis-kepada-masyarakat/diakses

Kampung, A. (2020, March 27). Angkatan Muda Muhammadiyah Konawe Gelar Aksi Bagi-bagi Masker Gratis I Kampung Sultra. https:// kampungsultra.com/angkatan-muda-muhammadiyah-konawegelar-aksi-bagi-bagi-masker-gratis/

Kane, J. M., Varner, J. M., Stambaugh, M. C., \& Saunders, M. R. (2020). Reconsidering the fire ecology of the iconic American chestnut. 11, 10.

KEPPRES No. 12 Tahun 2020 tentang Penetapan Bencana Nonalam Penyebaran Corona Virus Disease 2019 (COVID-19) Sebagai Bencana Nasional [JDIH BPK RI]. (2020). https://peraturan.bpk.go.id/Home/Details/135718/keppresno-12-tahun-2020

Khaidir, E., \& Suud, F. M. (2020). Islamic education in forming students' characters at as-shofa Islamic High School, pekanbaru Riau. International Journal of Islamic Educational Psychology, 1(1), 50-63. https://doi.org/10.18196/ijiep.1105

Kosasih, E., Raharusun, A. S., Dalimunthe, R. P., \& Kodir, A. A. (2020). Literasi media sosial dalam pemasyarakatan moderasi beragama dalam situasi pandemi Covid-19. Digital Library UIN Sunan Gunung Djati Bandung. http://digilib.uinsgd.ac.id/30707/ 
Alifuddin, Chaer \& Sukatin | Mitigation-Based Enlightenment Da'wah (Social Movement of MDMC Sulawesi-Southeast in Psychological Assistance to COVID-19 Survivors)

Madjid, A. (2014). Fenomenologi dan hermeneutik: perbandingan dua epistemologi. ETNOHISTORI: Jurnal Ilmiah Kebudayaan dan Kesejarahan, 1(1), 21. http://dx.doi.org/10.33387/jeh.v1i1.803

Hannan, A. (2020). Moderatisme dan Problem Konservatisme Beragama di Tengah Pandemi Global Covid-19. KURIOSITAS: Media Komunikasi Sosial Dan Keagamaan, 13(2), 167-197.

Martoredjo, N. T. (2020). Pandemi Covid-19: Ancaman atau Tentangan bagi Sektor Pendidikan?. E-Binus Library.

MDMC. (2019, June 14). https://mdmc.or.id/

MDMC Berbagi Strategi Penanggulangan Bencana di Forum ASEAN | Republika Online. (2019). https://republika.co.id/berita/nasional/sangpencerah/19/08/22/pwlf1u368-mdmc-berbagi-strategi-penanggulanganbencana-di-forum-asean/

MDMC Sultra Bagikan 9 Ribu Masker Secara Gratis Kepada Masyarakat | Faktual.Net. (n.d.). Retrieved 25 December 2020, from https://faktual.net/mdmc-sultrabagikan-9-ribu-masker-secara-gratis-kepada-masyarakat/

Media, K. C. (2020, March 12). Timeline Wabah Virus Corona, Terdeteksi pada Desember 2019 hingga Jadi Pandemi Global Halaman all. KOMPAS.com. https://www.kompas.com/tren/read/2020/03/12/113008565/timelinewabah-virus-corona-terdeteksi-pada-desember-2019-hingga-jadi

Media, K. C. (2021, May 17). Update Corona Dunia 17 Mei: 3,3 Juta Orang Meninggal Dunia karena Covid-19 Halaman all. KOMPAS.com. https:// www.kompas.com/tren/read/2021/05/17/093407265/updatecorona-dunia-17-mei-33-juta-orang-meninggal-dunia-karena-covid-19

Miles, M. B., \& Huberman. (1986). Qualitative Data Analysis: A Sourcebook of New Method. Sage Publication.

Misno BP, dkk, A. (2020). Covid-19; Wabah, Fitnah dan Hikmah. Pustaka Amma Amalia.

Moustakas, C. (1994). Phenomenology Research Methode. SAGA Publication Inc.

Muhammadiyah Inisiasi Gerakan Ketahanan Pangan Keluarga. (2020, July 15). Republika Online. https://republika.co.id/share/qdi58m423

Nurhayati, N., Idris, M., \& Al-Qadri Burga, M. (2018). MUHAMMADIYAH dalam Perspektif Sejarah, Organisasi, dan Sistem Nilai. TrustMedia Publishing.

Qodir, Z. (2019). Islam berkemajuan dan strategi dakwah pencerahan umat. Jurnal Sosiologi Reflektif, 209-234. https://doi.org/10.14421/jsr.v13i12.1630 
Alifuddin, Chaer \& Sukatin | Mitigation-Based Enlightenment Da'wah (Social Movement of MDMC Sulawesi-Southeast in Psychological Assistance to COVID-19 Survivors)

Sabara, S. (2020). Beragama dengan moderat di era pandemi Covid-19. MIMIKRI Jurnal Agama Dan Kebudayaan, 6(2), 131-149.

Sakban, A., Maemunah, M., \& Hafsah, H. (2020). Peran MDMC dalam pelayanan pendidikan dan psikososial untuk anak terdampak gempa bumi di Kabupaten Lombok Utara. Seminar Nasional Pendidikan Inklusif PGSDUNRAM 2020, 52-61.

Sani, K. R., \& Syamsuddin, S. (2020a). Peran Lembaga Muhammadiyah dalam Mitigasi Bencana di Kabupaten Sinjai. Jurnal Sosial Humaniora, 13(1), 37. https://doi.org/10.12962/j24433527.v13i1.6648

Sani, K. R., \& Syamsuddin, S. (2020b). Peran Lembaga Muhammadiyah dalam Mitigasi Bencana di Kabupaten Sinjai. Jurnal Sosial Humaniora, 13(1), 37. https://doi.org/10.12962/j24433527.v13i1.6648

Siahaan, M. (2020). Dampak pandemi Covid-19 terhadap dunia pendidikan. Jurnal Kajian Ilmiah, 1(1), 73-80. https:/ / doi.org/10.31599/jki.v1i1.265

Sohrabi, C., Alsafi, Z., O'Neill, N., Khan, M., Kerwan, A., Al-Jabir, A., Iosifidis, C., \& Agha, R. (2020). World health organization declares global emergency: A review of the 2019 T novel coronavirus (COVID-19). International Journal of Surgery, 76, 71-76. https://dx.doi.org/10.1016/j.ijsu.2020.02.034

Subiyanto, N. (2020). Disusun sebagai salah satu syarat menyelesaikan Program Studi Strata I pada Jurusan Psikologi Fakultas Psikologi. (Publication No. 7762720) [Skripsi]. Universitas Muhammadiyah Surakarta.

Supriatna, E. (2020). Wabah corona virus disease (Covid 19) dalam pandangan islam. SALAM: Jurnal Sosial Dan Budaya Syar-i, 7(6), 555-564. https://doi.org/10.15408/sjsbs.v7i6.15247

Survei LKSP: Muhammadiyah Paling Peduli Covid-19 | Republika Online. (2020). https:// www.republika.co.id/berita/qcqzcr327/survei-lkspmuhammadiyah-paling-peduli-covid19

Suud, F. M., Gaffar, A., Rouzi, K. S., \& Chaer, M. T. (2020). The role of islamic counselling in pandemic Covid 19: A conceptual study for developing positive emotion of parents and children. KONSELING RELIGI Jurnal Bimbingan Konseling Islam, 11(1), 18-35. http://dx.doi.org/10.21043/kr.v11i1.7705

Suwaryo, P. A. W., Sarwono, S., \& Yuwono, P. (2020). Peran Muhammadiyah Disaster Management Center dalam Mitigasi Bencana. Jurnal Ilmiah Permas: Jurnal Ilmiah STIKES Kendal, 10(1), 33-40. https:// doi.org/10.32583/pskm.v10i1.663

Syatar, A. S. A., Amiruddin, M. M., \& Rahman, A. (2020). Darurat moderasi beragama di tengah pandemi corona virus desease 2019 (Covid-19). KURIOSITAS: Media Komunikasi Sosial Dan Keagamaan, 13(1), 1-13. https://doi.org/10.35905/kur.v13i1.1376 
Alifuddin, Chaer \& Sukatin | Mitigation-Based Enlightenment Da'wah (Social Movement of MDMC Sulawesi-Southeast in Psychological Assistance to COVID-19 Survivors)

Tampubolon, I. (2016). Enlightening islamic preaching: Study on da`wah of Muhammadiyah in the contemporary era. FITRAH: Jurnal Kajian Ilmu-Ilmu Keislaman, 2(2), 1-16. https:// doi.org/10.24952/fitrah.v2i2.472

Telisik.id/news/sambut-ramadan-lazismu-sultra-bagi-sembako

Valerisha, A., \& Putra, M. A. (2020). Pandemi global Covid-19 dan problematika negara-bangsa: Transparansi data sebagai vaksin socio-digital?. Jurnal Ilmiah Hubungan Internasional. https://doi.org/10.26593/jihi.v0i0.3871.131$\underline{137}$

World Health International. (2020, July). https:// www.who.int 